\title{
THE ANALYSIS OF ERRORS OF OMISSION IN ENGLISH NARRATIVE COMPOSITION MADE BY EFL STUDENTS
}

\author{
Paramita Kusumawardhani \\ English Department, ABA Bina Sarana Informatika-Indonesia \\ paramita.pmi@bsi.ac.id
}

\begin{abstract}
This research was done to investigate kinds of errors of omission, classify them, explain the characteristics of the errors and evaluate the errors produced by the English foreign learners. Errors of omission could happen because the learners were still lack of form or grammar that is supposed to have in the sentence but the learners omit it. Writing is the most difficult skill in learning English as what is spoken is different with what is written. The writing skills are complex and certainly difficult to teach, requiring not only of grammatical and theoretical devises but also conceptual and judgmental elements. The research was done by using descriptive method and the data were collected from 20 English Foreign Learners' English Narrative Composition. The results found in the learners' English narrative composition are Omission of "Of" for about 5 errors or $25 \%$, Omission of "Auxiliary" for about 3 errors or 15\%, Omission of "Articles" for about 3 errors or $15 \%$, Omission of "Countable and Uncountable Nouns" for about 4 errors or $20 \%$, Omission of "Apostrophe's" for about 3 errors or 15\% and Omission of "Preposition" for about 2 errors or $10 \%$.
\end{abstract}

Keywords: Error Analysis, Errors of Omission, English Narrative Composition, EFL

\section{INTRODUCTION}

Abushihab (2014) explains in his research that Contrastive Analysis (CA) is based on Structuralism and Behaviorism which gained great popularity in the 1950s and 1960s. CA was formulated by Fries (1945) and developed by Ladies (1957). CA deals with the comparison of the structures of two languages or more and with the attempt of finding out the points of differences which are the main source of difficulty for language learner. The main aim of $\mathrm{CA}$ is to compare phonological systems, morphological systems, syntax and lexical meanings of two or more languages. The development of $\mathrm{CA}$ is the result of the need to teach L2 in the most effective way. As Lado (in Ellis) 1985, made clear that the teacher who had made a comparison of the foreign language with the native language of the students would know better what the real problems were and could provide efficient methods for teaching them.

Error Analysis (EA) henceforth is a branch of Applied Linguistics and has two 
functions. The first function is theoretical which has its place in methodology and describes the learners' knowledge of the target language. It also helps the researcher find out the relation between the knowledge and teaching the learners has been receiving. The practical area of EA is to overcome the mismatch between the knowledge of the learners and the demands of the situation.

Mourtaga (2004) pointed out that errors and mistakes are different from each other because an error cannot be self-corrected and is caused by a learner's inadequate knowledge of the target language whereas a mistake can be self-corrected. Gas and Selinker (2001) explained that a mistake can be self-centered, but an error is systemic.

Errors occur repeatedly and cannot be recognized by the learners. Hence, only the teacher or researcher could locate them. While mistakes according to Yuksel (2007) are not a result of deficiency in competence, they can be characterized by the slips of the pen or the slips of the tongue. Lapses may result from some factors such as memory failure and physical or mental fatigue. Richards et al (1985) describe errors as "The use of a linguistic item in a way which a fluent or native speaker of the language regards as showing faulty or incomplete action".

The interlanguage was introduced by Selinker (1972) and views the learner's verbal performance in L2 as a series of overlapping systems characterized by having aspects from both L1 and L2. Selinker talks about five central processes related to interlanguage:

1. Language transfer. It is about the process of the result of overgeneralization and of fossilization of items, rules and subsystems, which are transferred from the native language to the target language during the performance of interlanguage.

2. Transfer of training. It is about the errors in the process result from misleading and over generalized information given by textbooks and language teacher.

3. Strategist of second language learning. This is about the different strategies which affect the surface structure of sentences. This process is exemplified by tendency of learners to simplify the target language.

4. Strategies of second language communication. It is about the strategy which can be characterized by the avoidance of grammatical formatives like articles, plural forms, past tense forms, etc.

5. Overgeneralization of target language linguistic material. It is about the second 
language learners who tend to over generalize the rules in the target language in order to reduce them to a simpler level.

Hourani (2008) remarked that the primary causes of errors can be as follows: "Interlinguage errors and intralingual errors. Interlinguage errors are those which are related to the native language whereas intralingual errors are those which are due to the language being learned".

Correction is essential in helping the learners become more accurate in using the foreign language as Russel and Spada (2006) stressed that there is growing evidence that error correction is overall useful and can be helpful in L2 learning.

From the beginning, error analysis was beset with methodological problems. In particular, the above of typologies are problematic: from linguistic data alone, it is often impossible to reliably determine what kind of error a learner is making. Also, EA can deal effectively only with the learners' production, such as speaking and writing and EA is not related with the learners' perception such as listening and reading.

However, the learners' could be decreased or solved by conducting systematic analyzing to identify types and characteristics of the errors from the learners' production of speaking or writing in order to provide them with appropriate feedback and correction. Corder (1967) identified the significance of errors in three ways, they are: (1) Undertake a systematic analysis so the teachers can learn from their learners' linguistic progress and difficulties; (2) Errors provide evidence of how the learners learn or acquire the language and what strategies or procedures do they employ to achieve the learning goal; and (3) Errors are vital to the learners themselves since they are an essential device for them to test their hypotheses during the process of language learning.

Richard's \& Sampson (1974) supported that error analysis is an important tool for teachers to evaluate the learners' learning ability in order to set the priority to solve the learners' problems from the most frequent errors made by them.

\section{Kinds of Errors}

Based on the errors which happened commonly, Richards (1974) explained that the errors are:

1. Interlingua Errors. Interlingua errors are the errors happen in the learners' grammar which reflects the learners' mother tongue. These errors occur because there is an interference from the learners' mother tongue, ex.: It is a book green, not what 
you, what number?

2. Intralingua Errors. Intralingua errors is the errors happen in the learners' mother tongue but they don't reflect the learners' mother tongue, but it looks like a language which is made by the learners studying the target language as their mother tongue or looks like the errors in the target language occur because the grammar, itself, effects one another in the target language, ex : She can dances. I opening my book.

Based on Dulay (1982), he divided the errors into four types, they are:

1. Linguistic Category Taxonomy. This error based on the language components or the linguistic main elements which affect the errors. The language components consist of phonology (pronunciation), syntax and morphology (grammar), semantic and lexicon (meaningand vocabulary) and discourse (style). The linguistic main elements consist of the elements which compare each language component.

2. Surface Strategy Taxonomy. These errors explained about the way to change the strategy taxonomy which occurs.

3. Comparative Taxonomy. These errors based on the comparative between the structures of the errors in the second language with the certain another type construction. Comparative taxonomy consists of:

a. Developmental Errors (Intralingua Errors). This error happened because the learners' study the target language as their first language, ex.: Brother drink milk. Mother eat apple.

b. Interlingua Errors. This error happened commonly in the structure of the language becoming the semantic which is same as phrase or in the learners' native language, ex.: The woman beautiful. The sky cloudy.

\section{Communicative Effect Taxonomy.}

Surface Strategy Taxonomy and Comparative Taxonomy only focus on the errors happened in both of those taxonomies. Communicative taxonomy influences the classification with the errors from the listeners' or the readers' view.

Based on Hendrickson (1979), he grouped the errors into two types, they are:

1. Global Errors. Global errors are same as communicative errors. Global errors are the errors happened in the structure language which cause the learners misinterpret the oral or written message or consider that the message couldn't be 
understood in the whole contexts it.

2. Local Errors. Local errors are also called linguistics errors. Local errors are the errors happened in the structure language which seems strange or weird, but they didn't make the learners felt difficult in understanding the meaning of the sentences.

Based on the theories, the linguistics experts classified the errors into four types, they are:

1. Social Error. The social errors, the errors commonly occurred in the structure element. The errors could be happened because of the failure in application the English patterns which was based on the language which referred to the social context.

2. Register Error. This error happened because the language used didn't suitable for a certain occasion. Register error has a strong relationship in the usage of a language based on the situation. Usually the learners did the error because they haven't mastered if one language doesn't suitable to use in a certain situation. This happened because there is only limited material which discusses about the appropriateness in using a language for a certain occasion but this still considers as the learning process for the learners.

3. Referential Error. This error happened between the linguistics form with the objects or the situations happening outside the class. This error also happened because the learners haven't known what they thought and felt exactly.

4. Textual Error. This error happened related with the learners' knowledge based on the target language patterns. Corder (1971) explained, "The learner's errors are classified as a textual error when he does not select the structurally correct form in his sentence of intended relation between two sentences". Textual errors are:

a. Errors of Omission. Error of omission is the missing of some elements which should exist. Ex.: Woman is very beautiful. (It should be: The woman is very beautiful). She eat apple. (It should be: She eats an apple).

b. Errors of Addition. Error of addition is the adding of some elements which shouldn't exist. Ex.: I ate with bread and egg this morning. (It should be I ate bread and egg this morning). It is a meat. (It should be It is meat).

c. Errors of Selection. Error of selection is the use of words which shouldn't be used. Ex.: Do he go to school? (It 
should be Does he go to school?). She is thinking about you. (It should be She is thinking of you).

d. Errors of Ordering. Error of ordering is the elements which are not put in the proper place. Ex.: She doesn't know what is my name. (It should be She doesn't know what my name is). They know where do I live. (It should be They know where I live).

\section{The Nature of Writing}

Gloria (2013) stated, "The writing is good when it gives information or messages clearly and creates effective verbal dialogue to readers. It aims to give point of view of the ideas in text where it organizes in different way of writing such as narration, description, exposition, and argumentation". When students write a paragraph, they try to explore what they are thinking in mind, and they also concern with the language, meaning, and the structural of context related to English language acquisition as second or foreign language.

Mousapour (2011) said that writing must be related to the content, the language and grammatical rules. In order to avoid misunderstood, the students have to use correct sentences by creating a well written text and giving attention to the arrangement of words their composition to express their idea and to give the value of the writing to readers.

Writing is seen as a product constructed from the writer's command of grammatical and lexical knowledge, and writing development is considered to be the result of imitating and manipulating models provided by the teacher. For many who adopt this view, writing is regarded as an extension of grammar-a means of reinforcing language patterns through habit formation and testing learners' ability to produce well-formed sentences.

Alamargot et al. (2010) explained that developing writing is related to the writer's knowledge of language and writing exposure. Writing process is the way the writers give their ideas and messages to readers in the form of text. The writers present their ideas in various ways of writing such as narration, description, classification, comparison and contrast, argumentation and etc.

First narration is a basic writing strategy for presenting past event or activities. It can be used for a variety of purposes such as to illustrate and support ideas with anecdotes, to entertain readers with revealing stories, to analyze causes and possible effects with 
scenarios, and to explain procedures with process narrative. Second, description is a strategy used to create a dominant impression. For example, students describe a place in order to set a scene and make readers aware of its atmosphere and to describe people to show a kind of person's performance. Third, classification is aimed to classify number of items or ideas into a small number of classes. In a classification of paragraph, it is important to set up adequate categories and define what goes into categories. Fourth, comparison and contrast are to compare similar aspects or to contrast different aspects of two subjects, people or things. At last, argumentation is to argue ideas or opinion by giving some argues to proof the concept or research. A good paragraph must give readers complete information and unified by a controlling idea. It is organized form and can be understood what the paragraph is going to be about.

A paragraph is a group of sentences that works together to develop a main idea. Paragraphs are organized differently depending on their purposes. There are three main types of paragraphs in English: narrative, descriptive, and expository.

A narrative paragraph tells a story or a series of events. It tells what person or thing did during a particular period of time. As
White stated, "In narrative it is activities which are important; in description it is things. And in describing things we are usually more concerned with the noun rather than the verb phrase. Thus, description gives us a reason for teaching features of the noun phrase which, while occurring in other uses of the language, are of particular importance and frequency in describing things, people and places".

\section{The Nature of Narrative Composition}

Writing is the most difficult part in English subject as what it is said different from what it is written. Ron White and Valerie Ardnt (2011) stated, "Writing is far from being a simple matter of transcribing language into written symbols; it is a thinking process in its right". So, before the learners starting to write an English composition, they should master the English pattern correctly.

Mc. Dougal (2008) said, "A composition is a group of closely related paragraph that develop a single idea". David Crystal (2011) also said, "Writing a composition with vocabulary and structure which the student has either learnt to use orally or written exercises for each lesson. These exercises may be of various types. The range from filling blanks to the composition and may be modification, sentences composition and paragraph writing".

So the theory of the composition based 
on Mc. Dougal is the activity of writing which is started by mastering words and the grammar itself.

There are 4 kinds of compositions; they are argumentation, description, exposition and narration. George E. Wishon and Julia M. Burks (2010) stated, "Argumentation is used in persuading and convincing; it is closely related to exposition and is often found combined with it. Description is used to create a visual image of people, places and even of units of time-days, time of day or seasons, exposition is used in giving information, making explanation, and interpreting meanings and narration is the form of writing used to relate the story of acts or events".

Based on AS Hornby (2006), "Narration is telling of a story", meanwhile based on John M. Echols and Hassan Shadily (2006), "Narration adalah 1. Penceritaan, pengisahan; 2. Cerita, kisah". Narratives are stories. Narratives are plots. They are essays that tell a story, hopefully in an interesting way, that also convey themes. Often, if you are asked to write a narrative essay, you will not be asked to research a theory or topic. Rather, you will be asked to use your imagination instead of a bibliography. You may need to research for this narrative essay; nonetheless, the writing of it may come more easily to you for you do not need to quote specific words from primary sources.

A narrative paragraph tells a story or a series of events. It tells what person or thing did during a particular period of time. As White (2011) stated, "In narrative it is activities which are important; in description it is things. And in describing things we are usually more concerned with the noun rather than the verb phrase. Thus, description gives us a reason for teaching features of the noun phrase which, while occurring in other uses of the language, are of particular importance and frequency in describing things, people and places".

\section{METHODS}

Descriptive method was used to do the research. There are 3 types of descriptive method, they are observational method, case study method and survey method. Observational method as a part of descriptive method was used to take the data.

Descriptive method was used as Best (1974) stated, "Descriptive method is the method which tries to give the explanation about the symptoms relating with the recent situation. It consists on the effort of giving the 
note, the analysis and the interpretation of the recent symptoms which have the characteristics as follows: try to give the fact, straight to the problem and the recent variables aren't manipulated by the researcher".

The learners' English narrative compositions were used as the research instruments and they were taken from 20 learners and it was taken by asking the learners to make English narrative composition. After that, identifying, classifying, analyzing and correcting were done in order to know what kinds of syntax were found in the learners' English compositions.

\section{FINDINGS AND DISCUSSION}

After collecting, identifying, describing, explaining and correcting the errors, there are some errors found in the learners' English narrative composition. The errors are explained below:

Table 1. Omission of "Of"

\begin{tabular}{|c|c|}
\hline $\begin{array}{l}\text { STUDENTS' } \\
\text { ERRORS }\end{array}$ & THE CORRECTION \\
\hline $\begin{array}{lll}\text { 1. } & \text { I was still } \\
\text { exhausted } & \\
\text { because } & \text { the } \\
\text { monkeys. } & \end{array}$ & $\begin{array}{l}\text { I was still exhausted } \\
\text { because of the monkey. }\end{array}$ \\
\hline $\begin{array}{l}\text { 2. ... because the } \\
\text { broken car }\end{array}$ & $\begin{array}{l}\ldots \text { because of the } \\
\text { broken car }\end{array}$ \\
\hline $\begin{array}{l}\text { 3. She took care } \\
\text { her baby last } \\
\text { time }\end{array}$ & $\begin{array}{l}\text { She took care of her } \\
\text { baby last time }\end{array}$ \\
\hline $\begin{array}{l}\text { 4. I am thinking } \\
\text { my final test }\end{array}$ & $\begin{array}{l}\text { I am thinking of my } \\
\text { final test score }\end{array}$ \\
\hline
\end{tabular}

\section{score}

5. There are many There are many kinds kinds people at of people at the beach the beach

Based on the errors above, most of errors were done because the learners still don't know about the rules of using "Of". "Of" is usually used after verb, such as; rest, because, care, kind and think and "Of" is usually used before noun.

Table 2. Omission of "Auxiliary"

\begin{tabular}{ll}
\hline $\begin{array}{l}\text { STUDENTS' } \\
\text { ERRORS }\end{array}$ & THE CORRECTION \\
\hline 1. The very happy & $\begin{array}{l}\text { They were very happy } \\
\text { last holiday }\end{array}$ \\
last holiday & $\begin{array}{l}\text { I was tired } \\
\text { 2. I tired } \\
\text { 3. I had been to I had been to Bali } \\
\text { Bali when I two when I was teo years } \\
\text { years old }\end{array}$ old \\
\hline
\end{tabular}

From the errors above, the learners made the errors of auxiliary. There are some auxiliary verbs, such as; can, could, may, might, shall, should, will, would, ought to. Verb 1 or bare infinitive is usually used after auxiliary verbs. Is, am, are, was and were are also kinds of auxiliary verbs. They are used before adjective, present participle and noun.

Table 3. Omission of "Articles"

\begin{tabular}{l} 
STUDENTS' \\
ERRORS \\
\hline $\begin{array}{l}\text { There was an } \\
\text { unicycle near the } \\
\text { beach }\end{array}$
\end{tabular}

2. We drank a We drank (-) coffee coffee last time last time

3. A moon was so The moon was so bright last night bright last night

The errors above articles. A, an, the and zero article (-) are kinds of articles. $A$ is used 
for consonant sound; an is used for vowel sound; the is used for specific things, place at home, things in the universe and things which are mentioned again; zero article (-) is used for uncountable noun.

The errors about Countable and Uncountable nouns (Table 4). There are some words that can be used for countable nouns, such as; many, some, any, a lot of, several, a few. $-s$, -es and -ies are usually written after countable nouns. The words such as much, a little, some and any are usually used to show about uncountable nouns.

Table 4. Omission of "Countable and Uncountable Nouns"

\begin{tabular}{l}
\hline $\begin{array}{l}\text { STUDENTS' } \\
\text { ERRORS }\end{array}$ \\
$\begin{array}{l}\text { 1. There were so There were so many } \\
\text { many tourist at } \\
\text { the beach }\end{array}$ \\
2. We arranged We arranged some \\
some puzzle puzzles \\
3. There wasn't \\
many coffee left coffee left in the cup \\
in the cup beach \\
There was many \\
white sand at the sand at the beach \\
beach
\end{tabular}

Table 5. Omission of "Apostrophe's/

\begin{tabular}{l}
\multicolumn{3}{c}{ Possessive" } \\
\hline $\begin{array}{l}\text { STUDENTS' } \\
\text { ERRORS }\end{array}$ \\
\hline $\begin{array}{l}\text { We went to We WORRECTION } \\
\text { Rangunan by by father's car } \\
\text { father car }\end{array}$ \\
2. I stayed in my I stayed in my aunt's \\
aunt house last house last holiday \\
holiday \\
3. .. so Lisa wore ... so Lisa wore my \\
my sister's t- sister's t-shirt \\
shirt
\end{tabular}

The errors above are about Apostrophe's. Apostrophe's is written before noun and the noun can besingular or plural.

Table 6. Omission of "Preposition" STUDENTS' THE CORRECTION ERRORS

1. We went there We went there at six six o'clock o'clock

2. The sun on our The sun above our head was so head was so bright last bright last time time

The errors above are about preposition. There are many kinds of preposition, such as; in, on, above, under, below, beside, to, from, in front of, at, by, behind, between, along, through, etc. Preposition is written before noun.

\section{CONCLUSIONS}

Learning a foreign language demands not only willingness but also practice and commitment by both learner and teacher as well. Indeed, the process of language learning depends on the decisions and involvement of the learners, based on their experience of life and language as individuals. A better understanding of the learner can help the teacher understand what elements are playing a role in the learners' learning process. Likewise, by analyzing and recognizing learners' errors, we may come to value the fact that errors are the most significance evidence 
of their efforts to follow the path of the learning process.

Based on the errors found in the learners' English narrative composition, most of them made the errors because (1) the learners haven't understood and mastered the target language so they still made the sentences in their mother tongue; (2) most the errors are in textual error; (3) the learners' mother tongue influenced them much in making the target language; (4) the errors done by the learners perhaps happened because of the teacher's style in teaching; and (5) the learners weren't used to write or make an English narrative composition by the English teachers so they got some difficulties when they were asked to make an English narrative composition.

After being doing some steps based on Corder, the errors found in the learners' English narrative composition are Omission of "Of" for about 5 errors or $25 \%$, Omission of "Auxiliary" for about 3 errors or $15 \%$, Omission of "Articles" for about 3 errors or $15 \%$, Omission of "Countable and Uncountable Nouns" for about 4 errors or $20 \%$, Omission of "Apostrophe's" for about 3 errors or 15\% and Omission of "Preposition" for about 2 errors or $10 \%$.

Error analysis is an important instrument for teachers to not only find out the learners' language difficulties, but also to evaluate their ability and progress of linguistic development. Therefore systematic error analysis should be widely informed to and undertaken by second or foreign language teachers of all levels. Nonkukhetkhong (2013) suggested that the results of an error analysis can be used for further research to solve the learners' problems, for example, providing the learners with noticing grammar lessons, developing error analysis exercises, promoting selfcorrection and peer-correction, enhancing the use of grammar through communicative activities or implementing other teaching techniques to reduce the grammatical errors.

\section{REFERENCES}

Abushihab, I. (2014). An Analysis of Grammatical Errors in Writing Made by Turkish Learners of English as a Foreign Language. International Journal of Linguistics, 6(4), pp. 213-223. DOI: 10.5296/ijl.v6i4.6190.

Alamargot, Dennis and Fayol, Michel. (2010). Modelling Development of Written Composition. Journal of Second Language Writing. 23-47.

Best, John, W. (1974). Research in Education. New Jersey: Prentice Hall.

Corder, S. P. (1967). The Significance of 
Learner's Errors. International Review of Applied Linguistics. Pp. 160-170.

Corder, S. P. (1971). Error Analysis and Interlanguage. Hongkong: Oxford University Press.

Crystal, David. (2011). A Dictionary of Linguistics and Phonetics. USA: Cambridge University Press.

Dougal, Mc. (2008). Little English. USA: Cambridge University Press.

Dulay, Heidi. (1982). Language Two. New York: Oxford University Press.

Echols, John M. and Hassan Shadily. (2006). Kamus Inggris Indonesia. Jakarta: PT. Gramedia.

Ellis, R. (1996). The Study of Second Language Acquistion. Oxford: Oxford University Press.

Fries, C.C. (1945). Teaching and Learning English as a Foreign Language. Michigan: University of Michigan.

Gass, S. \& Selinker, L. (2001). Second Language Acquisition: An Introductory Course. Lawrence: Erbaum.

Heaton, J.B. (1988). Writing English Language Tests. New York: Longman Group.

Hendrickson, J. M. (1979). Error Analysis and Error Correction in Language Teaching. Singapore: SEAMO RECL.

Hornby, AS. (2006). Oxford Advanced Learner's Dictionary of Current English. New York: Oxford University Press.
Hourani, T. M. (2008). An Analysis of the Common Grammatical Errors in the English Writing Made by $3^{\text {rd }}$ Male Secondary Students in the Eastern Coast of the UAE, Dissertation, Institute of Education, British University in Dubai.

Lado, J. (1957). Linguistics across Culture. Michigan: University of Michigan Press.

Mourtaga, K. R. (2004). Investigating Writing Problems among Palestinian Students: Studying English as a Foreign Language. Indiana: Author House.

Mousapour, Giti. (2011). A Study of EFL Learners' Writing Skill. Intenational Journal of English Linguistics. Pp. 299307.

Nonkukhetkhong, K. (2013). Grammatical Error Analysis of the First Year English Major Students, Udon Thani Rajabhat University. The Asian Conference on Language Learning, pp. 117-126.

Richard, Jack C. (1974). Error Analysis A Non Contrastive Approach to Error Analysis. London: Longman Group.

Richard, et al. (1985). Longman Dictionary of Applied Linguistics. Essex: Longman Group Limited.

Richards, J. C. \& Sampson, G. P. (1974). The Study of Learner English. Reprinted in J. C. Richards. (Ed.) (1994). Error Analysis. Perspective on Second Language Acquisition. (13 ${ }^{\text {th }}$ ed). London: Longman.

Ron, White, and Valerie Ardnt. (2011). Process Writing. London: Longman Group. 
Russel, J., \& Spada, N. (2006). The Effectiveness of Corrective Feedback for the Acquisition of L2 Grammar. In Norris and Ortega (006) (Ed.) Synthesizing Research on Language Learning and Teaching. Hawi: John Benjamins.

Selinker, L. (1972). Interlanguage, IRAL: International Review of Applied Linguistics, 10. Connor, U. (1996).
Contrastive Rhetorics. USA: Oxford University Press.

Wishon, George E., and Julia M. Burks. (2010). Let's Write English. New York: American Book Company.

Yuksel, G. (2007). Grammatical Errors in the Compositions Written by Turkish Learners of English, Master Thesis. Erzrum: Ataturk University. 